\title{
Corporate Governance and Operational Risk Disclosure: Evidence from Shariah-Compliant Companies in Malaysia
}

\author{
Nurhafiza Mohammad ${ }^{1}$, Rina Fadhilah Ismail ${ }^{*}$, Saunah Zainon ${ }^{3}$ \\ and Juliana Mohd Abdul Kadir ${ }^{3}$ \\ ${ }^{1}$ Kolej Profesional MARA Ayer Molek, Melaka, Malaysia \\ ${ }^{2}$ Faculty of Accountancy, UiTM Selangor, Malaysia \\ ${ }^{3}$ Universiti Teknologi MARA Cawangan Johor, Malaysia
}

\begin{abstract}
This study aimed to examine the level of operational risk disclosure among Shariah-compliant companies in Malaysia. The relationship between corporate governance characteristics and operational risk disclosure was also examined by focusing on board characteristics, i.e. independent directors, audit committee meetings, Muslim directors, women directors and education levels of the directors. The sample comprised of 285 Shariah-compliant companies listed in the ACE Market of Bursa Malaysia for the financial years 2014 to 2018 . The study used content analysis to assess operational risk disclosure. The information disclosure was scored using an adapted disclosure index. Findings revealed that the disclosure of operational risk information in Shariah-compliant companies was at a moderate level, specifically not more than sixty per cent. More importantly, the analysis showed a positive significant relationship between a woman director and operational risk disclosure. However, a negative significant relationship was found between Muslim directors and operational risk disclosure. Other independent variables were found to have no relationship with the operational risk disclosure. The findings may provide future researchers and regulators with references for assessing the level of operational risk disclosure among public listed companies in Malaysia and are expected to deliver some improvement in examining other characteristics to strengthen the governance practices in Malaysia.
\end{abstract}

Keywords: operational risk disclosure, women director, Muslim director, Shariah-compliant companies

$\underline{\text { ARTICLE INFO }}$

Article History:

Received: 18 June 2021

Accepted: 20 September 2021

Published: 1 December 2021

* Corresponding author: Rina Fadhilah Ismail. Email: rinafadhilah@uitm.edu.my 


\section{INTRODUCTION}

Annual reports, which have become the key medium of communications between companies and external stakeholders, such as shareholders, financial analysts and creditors, have the function to facilitate the users in achieving informed economic decision-making. Evidence shows that the application of Shariah principles in business practices in many Muslim countries has satisfied both Muslim and non-Muslim investors' expectations. As Islamicbased business aims beyond materialistic and profitability goals, the entity is deemed a trustee and responsible towards owners and stakeholders. This concept of Amanah matches the idea of accountability towards satisfying stakeholders' needs (Othman \& Thani, 2010). Haniffa and Hudaib (2001) suggested that good reporting practices facilitate stakeholders in making business decisions and fulfilling their accountability to Allah. As Shariahcompliant companies are operated within the bounds of Islamic principles, they are expected to be more transparent in their reporting practices (Haniffa \& Hudaib, 2001). In the event their business is being exposed to a volatile and risky environment, disclosure of those risk information is paramount as identification of risk information is key to success of a business (Neifar \& Jarboui, 2018). Business operations can be exposed to a variety of risks causing potential losses or property damages that lead to a reduction in investors' confidence. As full disclosure of operational risk information is expected, debate continues about insufficient disclosure among listed companies (Probohudono et al., 2013). Thus, a low voluntary disclosure provided by Shariah-compliant companies (Ousama \& Fatima, 2010) indicates calls for more transparent disclosure augmented from both regulators and shareholders.

It has been reported that increasing numbers of collapsed companies in Malaysia were due to ineffective corporate governance imposing sufficient reporting (Ho \& Taylor, 2013; Li et al., 2013; Tengku Sulaiman \& Ahmad, 2017). Despite the importance of corporate governance and risk reporting of Shariah-compliant companies, the areas have not been sufficiently investigated (Mazri et al., 2018; Neifar \& Jarboui, 2018; Nugraheni \& Azlan Anuar, 2014; Rosli et al., 2017). Ideally, shariah-compliant companies practising good corporate governance should be more transparent and show an increase in accountability in disclosing their corporate activities and operations. Failures in corporate reporting and corporate governance 
practices in Malaysia are caused by lack of integrity and poor corporate governance. Thus, shariah-compliant companies need to practise effective corporate governance such as segregating duties among board members, which can be assessed from board size, role duality and presence of nonexecutive directors (Al-Maghzom et al., 2016; Elshandidy et al., 2013). Evidence shows that effective corporate governance enhances the quality of reporting, brings a greater impact on improving business efficiency, reduces fraud and improves internal control systems (Barakat \& Hussainey, 2013; Muhamad et al., 2009) regulation, and supervision on the quality of risk reporting in the banking industry, as proxied for by operational risk disclosure (ORD.

Therefore, the main objective of this study was to examine the influence of corporate governance characteristics on the operational risk disclosure practised by Shariah-compliant companies. Specifically, this study intended to examine several board characteristics to enhance understanding of how Shariah-compliant companies in Malaysia discharge their transparency through reporting practices with regard to potential risks that impacted their business.

The paper is structured in the following way. The next section contains a review of the literature on corporate governance and operational risk disclosure in Malaysia and the hypotheses. The third section details the methodology used and discusses the measurement of variables. The fourth section presents and interprets the results of hypothesis testing, while the final section concludes.

\section{LITERATURE REVIEW AND HYPOTHESES DEVELOPMENT}

\section{Operational Risk Disclosure among Shariah-Compliant Companies in Malaysia}

The Shariah principle forbids companies to be involved in activities related to gambling (maysir/qimar), ambiguity (gharar), interest (riba), and do not sell or manufacture non-halal products that are prohibited by Shariah principle (Wan Ismail et al., 2015). It is compulsory for Shariah- 
compliant companies to adhere to Islamic values, such as accountability and transparency, as required by Islam, to give full commitment according to Shariah law in all aspects of life (Ahmed Haji \& Mohd Ghazali, 2013; Rosli et al., 2017).

As they also face several risks in their business and operations, they are expected to be more transparent in their disclosure by providing relevant and useful information in order to attract both Muslim and non-Muslim investors, build a good public image and enhance companies' reputation (Morris \& Bartkus, 2015; Sun \& Cui, 2014). Disclosing operational risk information in annual reports improves transparency which can boost and increase shareholders value, help in decision making and maintain investor's confidence (Adamu, 2013; Ramli et al., 2019).

According to Naude and Chiweshe (2017), operational risk comprises the risk of opportunity cost or economic loss due to insufficient procedures and policies, disruption on operations due to failure of systems and facilities, non-compliance with regulations, failure of internal controls, fraud and health and safety. Operational risk disclosure can be classified into two subcategories, namely operational risk threat and operational risk management. Operational risk threat includes the risk of safety and health, operational problems within the company and litigation and legal suites. Meanwhile, operational risk management consists of corporate assurance plans, internal controls, risk management, policy and procedures (Ismail et al., 2016; Md. Sum \& Mahussin, 2017).

Therefore, high-quality operational risk disclosure shows that companies have the ability to manage risks and contribute to better financial stability by providing investors and stakeholders with better exposure and risk management practices (Adamu, 2013). Companies also need to disclose their operational risk to prove that they have a proper risk management process and reduce the perception of agency costs (Nobanee \& Ellili, 2017).

\section{Independent Directors and Operational Risk Disclosure}

Independent directors on the board play an important role in influencing companies reporting practices. Their decision on disclosure indicates how management perceives the importance of stakeholders' information needs 
and responds to them (Black \& Kim, 2012; Hendry et al., 2010). According to Fama and Jensen (1983), the presence of independent directors in the board of directors is able to promote control and limit managerial opportunism. This may imply that the roles of independent directors help to improve the development of a company's performance and increase efficiency outcomes (Aguilera et al., 2019) as well as improve managerial decisions. Further, independent directors give significant benefits to their stakeholders as they are able to apply their independent judgment, skills and experiences when facing any conflict of interest in the companies (Nguyen et al., 2019; Mohd Saat et al., 2011; Zattoni \& Cuomo, 2010).

A study conducted by Elshandidy et al. (2013) showed a positive relationship as high board independence was likely to exhibit a higher level of voluntary risk disclosure. This finding is also consistent with that of another study by Lopes and Rodrigues (2007). A recent study by Neifar and Jarboui (2018) also found a positive relationship between independent directors on the board and operational risk disclosure. This study confirmed that an increase in the number of independent directors on the board would be able to provide a higher quality of corporate decisions and influence the disclosure of risk information. However, Al-Maghzom et al. (2016) showed an insignificant relationship with voluntary risk disclosure. Thus, we assume that there is a positive relationship between the independence of the directors and operational risk disclosure. From the above discussion, it is hypothesised that:

$\mathbf{H}_{\mathbf{1}}$ : There is a significant positive relationship between an independent board of directors and operational risk disclosure

\section{Audit Committee Meetings}

An audit committee is defined as an operating committee to the board of directors which is responsible for monitoring the financial reporting of the company to reduce asymmetry of information by disclosing information transparently. Regular audit committee meetings are able to enhance audit committee effectiveness as they are responsible for oversight of financial reporting and auditing activities (Allegrini \& Greco, 2011; Ika \& Mohd Ghazali, 2012). 
According to Allegrini and Greco (2011), the more frequent audit committee meetings are conducted, the more members can express their judgment on a firm's accounting choice of principles, disclosures and estimations. They found a positive relationship between frequency of audit committee meetings and the disclosure of projected and risk information consistent with the recommendations of the national Governance Codes that requires the audit committees play their roles in companies. A study conducted by Al-Maghzom et al. (2016) also showed a significant positive relationship in which they found that banks with more frequent audit committee meetings had increased motivations to disclose more risk information which was also consistent with the prior literature. However, Neifar and Jarboui (2018) had conducted a study on corporate governance and operational risk disclosure in Islamic banks belonging to various countries, such as Saudi Arabia, Bahrain, Jordan, Kuwait, Qatar, EmiratesArabes-United, Abu Dhabi, Dubai, Malaysia and Iran. They found that there was an insignificant relationship between audit committee meetings and operational risk disclosure. This finding is consistent with that of a study performed by Alnabsha et al. (2018) among Libyan companies. Therefore, the following hypothesis was developed:

$\mathbf{H}_{2}$ : There is a significant positive relationship between the frequency of audit committee meetings and operational risk disclosure.

\section{Muslim Directors}

Prior researchers have studied Muslim directors with disclosure (A1Shammari, 2013; Mazri et al., 2018; Rosli et al., 2017). Al-Shammari (2013) studied voluntary disclosure of Shariah Compliant companies in the Kuwait Stock Exchange and mentioned that higher Muslim directors enhanced management responsibilities to demonstrate accountability and transparency. Mazri et al. (2018) also state that board composition in the company positively influences Islamic Social Reporting. The involvement of Muslim directors is expected to positively influence the disclosure in the companies, especially in operational risk information due to the strong belief in Islamic values. Abd-Mutalib et al. (2017) stated that having a larger number of Muslims on board enables them to carry out their responsibilities in line with the commands by Allah SWT to protect the environment. It seems to highlight that it is a commitment to risk management in a company. Apart 
from that, they also found that the presence of Muslims on a board might influence the corporate social responsibility (CSR) reporting performance. Further, Othman (2009) and Haniffa and Hudaib (2001) exerted that the presence of Muslim directors on a board as one of the important elements which is able to influence management decision making and powerful in influencing management decisions to disclose more information in company reports when a Muslim director is present in the board. However, Rosli et al. (2017) found no significant relationship between voluntary risk disclosures and the presence of Muslim directors although it was expected that their presence would be able to influence the disclosure culture and practices due to their devotion to Islamic values.

Therefore, the third hypothesis was developed as follows:

$\mathbf{H}_{3}$ : There is a significant relationship between Muslim directors on a board and operational risk disclosure.

\section{Women Directors}

Gender diversity can be classified as a critical component of a corporate governance structure as it affects a board's effectiveness. Allini et al. (2016) stated that differences in gender lead to a variety of skills and behaviour among board members. There are mixed results regarding woman directors from previous literature. Adams and Ferreira (2009) and Nielsen and Huse (2010) revealed that women on a board could influence decisions positively as they had an interactive leadership style and effective communication with their subordinates. A previous study by Saggar and Singh (2017) showed a positive and significant effect on risk disclosure which revealed that the diversity of gender could strengthen monitoring and promote growth opportunities. This finding is consistent with that of a study by Nitm et al. (2013) and Allini et al. (2016) who also found a positive correlation between gender and risk disclosure. There is a positive effect of gender diversity and the level of forward-looking information disclosure (Aribi et al., 2018). Another study by Al-Maghzom et al. (2016) also found that banks with women participation tended to disclose risk disclosure compared to men. The presence of women directors on a board with a higher quality of board governance is higher in transparency and integrity in preparing a company's report. However, findings from Manita et al. (2018) in their study on board 
gender diversity and environmental, social and corporate governance (ESG) disclosure showed that there was no significant relationship between board gender and ESG disclosure. A study by Allini et al. (2016) found a negative association where the presence of women in top management decreased the level of non-financial risk disclosure. Thus, the following hypothesis was developed:

$\mathbf{H}_{4}$ : There is a significant positive relationship between gender and operational risk disclosure.

\section{Education Background}

A previous study by Allini et al. (2016) stated that the diversity of educational background is important to ensure better monitoring and effectiveness from the top management. Hambrick and Mason (1984) posited that highly educated managers tend to adopt innovative activities and lean more towards risk-taking tendencies. Highly educated managers are more transparent and are able to influence to disclose more risk information (Mohd Ali, 2013). The utilisation of specific knowledge and skills in accounting and finance might help members of the board in the decision-making process, leading to an increase in the quality of risk disclosure (Bhagat et al., 2010). Findings from Mohd Ali (2013) showed that education background did not influence the decision of the Chief of the audit committee on corporate risk disclosure. Besides, Al-Maghzom et al. (2016) found that education had an insignificant correlation with the level of voluntary risk disclosure in Saudi Arabian Banks. It was supported by studies done by Gul and Leung (2004) and Allini et al. (2016), who found a significant negative relationship between the educational background of the board of directors and risk disclosure. The educational background of the board of directors did not influence the disclosure of related risk information, which may be influenced by other considerations. Therefore, the following hypothesis was formulated:

$\mathbf{H}_{5}$ : There is a significant negative relationship between educational background of the board of directors and operational risk disclosure. 


\section{Control Variables: Company size}

This study used company size as a control variable. Previous literature has indicated a positive association between company size and risk disclosure (Allini et al., 2016; Elshandidy \& Neri, 2015; Samaha et al., 2015; Siman et al., 2019). Ousama and Fatima (2010) pointed out that company size tends to disclose more information in order to maintain a good company image and external funding purposes.

\section{RESEARCH METHODOLOGY}

\section{Sample Selection and Data Collection}

This study selected samples from companies listed in the ACE Market, the second board of Bursa Malaysia that consisted of high potential growth companies which implement advanced electronics, information technology, telecommunications, automation manufacturing systems, biotechnology and genetic engineering, healthcare, advanced material, energy, aerospace, transportation and other emerging technologies between 2014 and 2018. As ACE Market companies are characterised by limited financial resources, there is evidence that the possible risks in business growth can be reduced when quality disclosure is present, indicating risk mitigation action is in place. Hence, the use of extensive disclosure can be an alternative to signal investors that their businesses have a future growth potential (Ramli et al., 2019; Sulong et al., 2013).

The list of Shariah Compliant Securities prepared by the Shariah Advisory Council of the Securities Commission Malaysia, dated 30 November 2018 was used to select the sample of shariah-compliant companies under the ACE Market of Bursa Malaysia. Overall, 689 companies listed in Bursa Malaysia were classified as Shariah-compliant companies under the Shariah Advisory Council of the Securities Commission Malaysia. Out of these 90 companies were listed in the ACE Market. A summary of the final sample selected is presented in Table 1 below: 
Table 1: Summary of Total Sample

Initial sample of Shariah-compliant companies listed in ACE Market Bursa Malaysia

Unavailable Annual Report or Incomplete Data (2014 -2018)

Total Sample

Final sample for 5 years (2014-2018)

Data was collected from Datastream Thomson Reuters and companies' annual reports available on companies' official websites. The period from 2014 to 2018 was chosen to help provide the most recent picture of the voluntary reporting practices of the sampled companies.

\section{Measurement of Dependent Variable}

A content analysis approach was used to measure the dependent variable of operational risk disclosure by employing a disclosure index. This study used a disclosure index adapted from Ismail (2015), comprising five categories of operational risk disclosure, namely customer; product development; efficiency and performance; environmental disclosure and health and safety. An unweighted method of scoring was used to assess the level of risk disclosure, where the items were assigned a score of 1 if an item of risk was disclosed. The items were assigned a score of 0 if no item of risk was disclosed (Ismail, 2015; Siman et al., 2019; Neifar \& Jarboui, 2018). The disclosure index outlined 18 items of operational risk items from a conventional perspective and an Islamic perspective, such as providing halal products and services to customers and obeying Shariah principles. The total score of operational risk disclosure was calculated based on the summation of scores for each item, as follows:

$$
O R D=\sum_{i=1}^{m} D i \div \sum_{i=1}^{n} D i
$$

Where: $O R D=$ Operational risk disclosure

$D i=1$ if the item is disclosed; 0 if the items is not disclosed

$n$ = Aggregation of all applicable items

$m=$ number of actual items disclose 


\section{Operationalisation of Dependent, Independent Variables and Control Variables}

All independent variables were collected from companies' annual reports and DataStream. Table 2 summarises the operationalisation of independent variables and control variables.

Table 2: Summary of the Measurements of the Dependent, Independent and Control Variables

\begin{tabular}{|c|c|c|}
\hline \multicolumn{3}{|c|}{ Independent variables: Corporate governance characteristic } \\
\hline Abbreviation & Particular & Measurement \\
\hline ORD & $\begin{array}{l}\text { Operational Risk } \\
\text { Disclosure }\end{array}$ & $\begin{array}{l}18 \text { items of an adapted operational } \\
\text { risk disclosure index }\end{array}$ \\
\hline INDIR & Independent Directors & $\begin{array}{l}\text { Percentage }(\%) \text { of the independent } \\
\text { directors on board }\end{array}$ \\
\hline ACMEET & $\begin{array}{l}\text { Audit Committee } \\
\text { Meetings }\end{array}$ & Number of audit committee meetings \\
\hline MUSDIR & Muslim Directors & $\begin{array}{l}\text { Percentage of Muslim directors on } \\
\text { board }\end{array}$ \\
\hline WOMDIR & Women Directors & $\begin{array}{l}\text { A dummy variable, } 1 \text { if the board } \\
\text { contains female directors and } \\
\text { otherwise } 0\end{array}$ \\
\hline EDU & Education & $\begin{array}{l}\text { A dummy variable, } 1 \text { if one of the } \\
\text { board members holds a bachelor's } \\
\text { degree and above and otherwise } 0\end{array}$ \\
\hline SIZE & Company Size & $\begin{array}{l}\text { Total asset of a company at the end } \\
\text { of a reporting year }\end{array}$ \\
\hline
\end{tabular}

\section{RESULTS AND DISCUSSION}

\section{Descriptive Statistics}

Table 3 presents a summary of operational risk disclosure by category and total. The category of operational risk disclosure that occurred the most in annual reports was product development, indicated by $35.58 \%$; followed by efficiency and performance (26.01\%); environmental items $(17.51 \%)$; health and safety $(10.99 \%)$, and the lowest category was the customer $(9.91 \%)$. 
Table 3: Summary of Disclosure Score for Operational Risk Disclosure ( $\mathrm{N}=\mathbf{2 8 5})$

\begin{tabular}{lcc}
\hline \multicolumn{1}{c}{ Category of ORD } & Percentage (\%) & Total Score \\
\hline Customer & 9.91 & 295 \\
Product Development & 35.58 & 1059 \\
Efficiency \& Performance & 26.01 & 774 \\
Environmental & 17.51 & 521 \\
Health \& Safety & 10.99 & 327 \\
Total operational risk & 100.00 & 2976 \\
\hline
\end{tabular}

Table 4 exhibits descriptive statistics of the dependent and independent variables. As shown in the Table, the mean score of operational risk disclosure for each company was 10.44 out of a total score of 18 . On average, this indicated that companies moderately disclosed operational risk information, which totalled $58 \%$ of the items in their annual reports. For board characteristic of independent directors (INDIR), the mean value indicated $50.09 \%$, which implied that, on average, $50 \%$ of directors on board of shariah-compliant companies were independent directors. The highest proportion of $75 \%$ independent directors were on the board among the Shariah-compliant companies in the ACE Market. With regard to the number of audit committee meetings (ACMEET), a mean value of 4.77 posited that almost 5 times of the audit meetings were held, as reported in the annual reports. The percentage of Muslim directors (MUSDIR) was found at the maximum of $83 \%$, with a mean value of $20.66 \%$, indicating only $20.66 \%$ of Shariah-compliant companies in the ACE Market were governed by Muslim directors who sat on the board. Two dummy variables of women director (WOMDIR) and education (EDU) showed a mean score of 0.43 and 0.91, respectively. Further investigations on the proportion of women and men directors on the board were conducted, and the results showed that women directors were 122 (or $43 \%$ ) compared to 163 men directors (or 57\%) based on the 5-year annual reports observation. For education background, the majority of the companies had at least one of the board members who had a bachelor's degree, indicated by 258 or $97 \%$, while $3 \%$ of all companies did not have board members with a bachelor's degree. 
Table 4: Descriptive Statistics for Dependent and Continuous Independent Variables

\begin{tabular}{lccccc}
\hline \multicolumn{1}{c}{ Variable } & $\mathbf{N}$ & Minimum & Maximum & Mean & Std. Deviation \\
\hline ORD & 285 & 5 & 17 & 10.44 & 2.386 \\
INDEP & 285 & .00 & 75.00 & 50.0909 & 12.18157 \\
ACMEET & 285 & 0 & 10 & 4.77 & 1.190 \\
MUSDIR & 285 & .00 & 83.00 & 20.6568 & 23.47164 \\
WOMDIR & 285 & 0 & 1 & .43 & .496 \\
EDU & 285 & 0 & 1 & .91 & .293 \\
\hline
\end{tabular}

\section{Multiple Regression Analysis}

This study conducted a multiple regression analysis to examine $\mathrm{H} 1$ to $\mathrm{H} 5$ that predicts the relationship between corporate governance characteristics and operational risk disclosure among Shariah-compliant companies. The multiple regression coefficient analysis was performed to explain and describe the relationship between one dependent variable with two or more independent variables. Particularly, the data should be normally distributed before multiple regression analyses were conducted. The model is presented as follows:

$$
\begin{aligned}
\text { ORD }= & \beta_{0}+\beta_{1} \text { INDEP }+\beta_{2} \text { ACMEET }-\beta_{3} \text { MUSDIR }+\beta_{4} \text { GENDER }- \\
& \beta_{5} \text { EDUC }+\beta_{6} \text { CSIZE }+\varepsilon
\end{aligned}
$$

Where:

$\begin{array}{ll}\text { ORD } & =\text { Operational risk disclosure } \\ \text { INDIR } & =\text { Independent directors } \\ \text { ACMEET } & =\text { Audit committee meetings } \\ \text { MUSDIR } & =\text { Muslim directors } \\ \text { WOMDIR } & =\text { Women directors } \\ \text { EDUC } & =\text { Education } \\ \text { SIZE } & =\text { Company's size }\end{array}$

According to Cohen (1988), R-square is used to determine the explanatory power of the independent variables included in a model. Based on Cohen's (1988) assessment criterion, the R-square value equal to 0.26 or more is considered to be substantial, 0.13 moderate, and 0.02 
weak. As shown in Table 4 the R-squared of the model was $7.4 \%$. This indicated a weak explanatory power of the predicted and observed values of outcomes. However, the overall model showed a significant value at $p$ $<0.001(\mathrm{~F}=3.811)$.

Table 5 reports the results of multiple regression analysis. The results showed that Muslim directors (MUSDIR) and women directors (WOMDIR) had a significant relationship with operational risk disclosure. The results showed that MUSDIR had a negative significant relationship with operational risk disclosure at a significance value $\mathrm{p}<0.05(\mathrm{t}=-2.601, \mathrm{p}=0.01)$. A significant negative relationship between Muslim directors and operational risk disclosure indicated that non-Muslim directors had more influence in reporting operational risk information. This finding is consistent with that of a previous study in Malaysia by Abdul Rahman et al. (2018)Muslim Chairman and Muslim board of directors in mitigating earnings management via real activities manipulation. Design/methodology/approach: In total, 656 firm year-observations from 2007 to 2014 of Malaysian Top 100 firms listed on Bursa Malaysia is used to examine the relationship between real earnings management (REM who found that Muslim CEOs and Chairmen did not influence the decisions made by the management. Therefore, H3 was accepted.

The results showed that WOMDIR have a positive significant relationship with operational risk disclosure at a significance value $\mathrm{p}<0.001(\mathrm{t}=3.364, \mathrm{p}=0.001)$. These findings are consistent with those of Al-Maghzom et al. (2016) and Zahid et al. (2019) who revealed that the existence of WOMDIR on board indicates an ability to influence board decisions, particularly the disclosure of operational risk information which improves the quality of governance as WOMDIRs have better oversight of management reporting (Soong \& Hooy, 2016). Thus, H4 is accepted.

On the other hand, the results showed INDIR $(\mathrm{t}=1.210, \mathrm{p}=.227)$, $\operatorname{ACMEET}(\mathrm{t}=-.083, \mathrm{p}=.934)$ and $\operatorname{EDU}(\mathrm{t}=-1.260, \mathrm{p}=.209)$ had insignificant influence toward the operational risk disclosure. The results of the current study are consistent with those of Al-Maghzom et al. (2016) who found no relationship between independent directors and education on voluntary risk disclosure. For audit committee meetings, the findings were consistent with those of Neifar and Jarboui (2018) who revealed an insignificant 
relationship between audit committee meetings and operational risk disclosure. This implies that more frequent audit committee meetings might not be an indicator for more operational risk disclosure practices among companies. Their practices might be influenced by other factors, such as board meetings and the size of audit committees. Therefore, H1, H2 and H5 were not supported.

Table 5: Multiple Regression Analysis

\begin{tabular}{lccc}
\hline Model & \multicolumn{2}{c}{ DV: Operational Risk Disclosure } \\
\hline $\mathrm{R}$ & & .276 & \\
$\mathrm{R}^{2}$ & & .074 & \\
Adjusted $\mathrm{R}^{2}$ & & 0.056 & \\
F-statistic (p-value) & & 3.811 & \\
Model Sig. & & $.001^{* * *}$ & $\mathrm{Sig}$. \\
& $\beta$ & $\mathrm{t}$ & .220 \\
Constant & -1.376 & -1.231 & .227 \\
INDIR & .072 & 1.210 & .934 \\
ACMEET & -.005 & -.083 & $.010^{* *}$ \\
MUSDIR & -.175 & -2.601 & $.001^{* * *}$ \\
WOMDIR & .386 & 3.364 & .209 \\
EDU & -.240 & -1.260 & .194 \\
SIZE & .081 & 1.302 & \\
\hline
\end{tabular}

${ }^{* *}$ Correlation is significant at the 0.05 level (2-tailed).

${ }^{* \star *}$ Correlation is significant at the 0.001 level (2-tailed).

\section{CONCLUSION}

This study contributes to the existing literature on corporate governance and disclosure practices in Malaysia. Taken together, the findings add substantially to our understanding of the importance of corporate governance characteristics to influence board decisions on operational risk disclosure among public listed companies. Effective mechanisms for corporate governance is vital to assist companies in enhancing the effectiveness of the management structure and transparent corporate disclosures. Hence, this study was carried out to determine the level of disclosure of operational risk information among Shariah-compliant companies listed in ACE Market. Further, the influence of board characteristics was also examined 
to investigate if there were significant relationships between corporate governance characteristics and operational risk disclosure by reviewing 285 annual reports for five years of observation $(2014-2018)$.

Based on Islamic principles, companies are encouraged to practice full disclosure and provide more information related to risks and accountability for their stakeholders; however, the findings revealed that the growth potential shariah-compliant companies listed under the ACE Market have been practising the disclosure on operational risk information at a moderate level of 58\% between 2014 and 2018. Although many benefits would be derived from disclosure, the Shariah-compliant companies listed in ACE Market of Bursa Malaysia still have not yet fully practised it (Mazri et al., 2018; Othman \& Thani, 2010). Therefore, directors in the board of shariah-compliant companies are also expected to be more transparent and accountable to be in line with Islamic principles. As such, this responsibility should be equally performed by both Muslim and non-Muslim directors without any disagreement due to differences in religion (Rosli et al., 2017). In a similar vein, a significant role for women as leaders has been acknowledged around the world. Women are characterised as having better oversight on management reporting, portraying an interactive style that enables them to propose new ideas to increase companies' transparency and accountability (Adams \& Ferreira, 2009; Farrell et al., 2016; Soong \& Hooy, 2016).

As the findings of this study are limited to data from Shariah-compliant companies in Malaysia listed in the ACE Market of Bursa Malaysia, it would be beneficial for future studies to include data from the Main Market and other countries to compare the level of operational risk disclosure practiced by Shariah-compliant companies worldwide. Future data collection can be expanded to include other communication media sources such as company prospectuses, interim reports, interviews and questionnaires to enhance the reliability of the data collected and provide better references. 


\section{REFERENCES}

Abd-Mutalib, H., Yahya, N. H., \& Taib, S. (2017). Muslim board of directors and corporate social responsibility reporting: Evidence from Malaysia. Advanced Journal of Technical and Vocational Education, 1(1), 203-213.

Abdul Rahman, R., Hj Omar, N., Rahman, A., \& Muda, R. (2018). Islamic ethical values of corporate top leadership and real earnings management. International Journal of Law and Management, 60(3), 869-884. https:// doi.org/10.1108/IJLMA-03-2017-0029

Adams, R. B., \& Ferreira, D. (2009). Women in the boardroom and their impact on governance and performance. Journal of Financial Economics, 94(2), 291-309. https://doi.org/10.2139/ssrn.1107721

Adamu, M. U. (2013). Risk reporting: A study of risk disclosures in the annual reports of listed companies in Nigeria. Research Journal of Finance and Accounting, 4(16), 140-148.

Aguilera, R. V., Marano, V., \& Haxhi, I. (2019). International corporate governance: A review and opportunities for future research. Journal of International Business Studies, 50(4), 457-498. https://doi. org/10.1080/03088837500000054

Ahmed Haji, A., \& Mohd Ghazali, N. A. (2013). The quality and determinants of voluntary disclosures in annual reports of Shari'ah compliant companies in Malaysia. Humanomics, 29(1), 24-42. https:// doi.org/10.1108/08288661311299303

Al-Maghzom, A., Hussainey, K., \& Aly, D. A. (2016). Corporate governance and risk disclosure: Evidence from Saudi Arabia. Corporate Ownership and Control Journal, 13(2), 145-166.

Al-Shammari, B. (2013). An investigation of voluntary disclosure by Kuwaiti Shariah -compliant companies. Journal of Economic and Administrative Sciences, 29(1), 21-41. https://doi.org/10.1108/10264111311319213 
Allegrini, M., \& Greco, G. (2011). Corporate boards, audit committees and voluntary disclosure: Evidence from Italian listed companies. Journal of Managerial Governance. https://doi.org/10.1007/s10997-011-9168-3

Allini, A., Manes Rossi, F., \& Hussainey, K. (2016). The board's role in risk disclosure: An exploratory study of Italian listed state-owned enterprises. Public Money and Management, 36(2), 113-120. https:// doi.org/10.1080/09540962.2016.1118935

Alnabsha, A., Abdou, H. A., Ntim, C. G., \& Elamer, A. A. (2018). Corporate boards, ownership structures and corporate disclosures: Evidence from a developing country. Journal of Applied Accounting Research, 19(1), 20-41. https://doi.org/10.1108/JAAR-01-2016-0001

Aribi, Z. A., Alqatamin, R. M., \& Arun, T. (2018). Gender diversity on boards and forward-looking information disclosure: Evidence from Jordan. Journal of Accounting in Emerging Economies, 8(2), 205-222. https://doi.org/10.1108/JAEE-05-2016-0039

Barakat, A., \& Hussainey, K. (2013). Bank governance, regulation, supervision, and risk reporting: Evidence from operational risk disclosures in European banks. International Review of Financial Analysis, 30, 254-273. https://doi.org/10.1016/j.irfa.2013.07.002

Bhagat, S., Bolton, B., \& Subramanian, A. (2010). CEO education, CEO turnover, and firm performance. Available at SSRN 1670219.

Black, B., \& Kim, W. (2012). The effect of board structure on firm value : A multiple identification strategies approach using Korean data. Journal of Financial Economics, 104(1), 203-226. https://doi.org/10.1016/j. jfineco.2011.08.001

Cohen, J. (1988). Statistical power analysis ( $2^{\text {nd }}$ ed.). Hillsdale NJ: Erlbaum.

Elshandidy, T., Fraser, I., \& Hussainey, K. (2013). Aggregated, voluntary, and mandatory risk disclosure incentives: Evidence from UK FTSE allshare companies. International Review of Financial Analysis, 30(2013), 320-333. https://doi.org/10.1016/j.irfa.2013.07.010 
Fama, E. F., \& Jensen, M. C. (1983). Separation of ownership and control. Journal of Law and Economics, 26(2), 301-325.

Farrell, L., Fry, T. R. L., \& Risse, L. (2016). The significance of financial self-efficacy in explaining women's personal finance behaviour. Journal of Economic Psychology, 54, 85-99. https://doi.org/10.1016/j. joep.2015.07.001

Gul, F. A., \& Leung, S. (2004). Board leadership, outside directors' expertise and voluntary corporate disclosures. Journal of Accounting and Public Polic, 23, 351-379. https://doi.org/10.1016/j.jaccpubpol.2004.07.001

Hambrick, D. C., \& Mason, P. A. (1984). Upper echelons: The organization as a reflection of its top managers. Academy of Management Review, 9(2), 193-206.

Haniffa, R., \& Hudaib, M. A. (2001). A theoretical framework for the development of the Islamic perspective of accounting. In Accounting, Commerce \& Finance: The Islamic Perspective International Conference 2001.

Hendry, K. P., Kiel, G. C., \& Nicholson, G. (2010). How boards strategise: A strategy as practice view. Long Range Planning, 43(1), 33-56. https:// doi.org/10.1016/j.lrp.2009.09.005

Ho, P. L., \& Taylor, G. (2013). Corporate governance and different types of voluntary disclosure: Evidence from Malaysian listed firms. Pacific Accounting Review, 25(1), 4-29. https://doi. org/10.1108/01140581311318940

Ika, S. R., \& Mohd Ghazali, N. A. (2012). Audit committee effectiveness and timeliness of reporting: Indonesian evidence. Managerial Auditing Journal, 27(4), 403-424. https://doi.org/10.1108/02686901211217996

Ismail, R. F. (2015). Voluntary risk disclosure and firm value creation: From the perspectives of the agency and signalling theories (Doctoral dissertation, Universiti Teknologi MARA). 
Ismail, R. F., Arshad, R., Ahmad, E. M., Shaffee, N. S., \& Mohd Pauzi, N. F. (2016). Risk reporting practices and organisational survivability. In Proceedings of the 27th International Business Information Management Association Conference - Innovation Management and Education Excellence Vision 2020: From Regional Development Sustainability to Global Economic Growth, IBIMA 2016.

Li, H., Jr, J. S. J., \& Yost, K. (2013). Corporate risk and corporate governance: another view. Managerial Finance, 39(3), 204-227. https:// doi.org/10.1108/03074351311302773

Lopes, T., \& Rodrigues, L. (2007). Accounting for financial instruments: An analysis of the determinants of disclosure in the Portuguese, 42, 25-56. https://doi.org/10.1016/j.intacc.2006.12.002

Manita, R., Bruna, M. G., Dang, R., \& Houanti, L. (2018). Board gender diversity and ESG disclosure: Evidence from the USA. Journal of Applied Accounting Research, 19(2), 206-224. https://doi.org/10.1108/ JAAR-01-2017-0024

Mazri, K. F., Ismail, R. F., Arshad, R., \& Kamaruzaman, S. A. (2018). Corporate governance attributes as determinants of the Islamic Social Reporting of Shariah-compliant companies in Malaysia. International Journal of Economics and Management, 12(Special Issue 1), 169-180.

Md.Sum, R., \& Mahussin, N. (2017). Risk management practices of a small enterprise: A case study on a bakery shop. In 4th International Muamalat and Entrepreneurship Conference (IMEC4) 2017.

Mohd Ali, M. (2013). Corporate risk disclosure, upper management characteristics, ownership structure and firm value: Malaysian evidence (Doctoral dissertation, RMIT University).

Mohd Saat, N. A., Karbhari, Y., Heravi, S., \& Md Nasir, A. (2011). Effective oversight roles of board of directors - The case of listed firms on Bursa Malaysia. World Review of Business Reserah, 1(1), 231-245. 
Morris, S. A., \& Bartkus, B. R. (2015). Look who's talking: Corporate philanthropy and firm disclosure. International Journal of Business and Social Research, 5(1), 1-14. Retrieved from http://www. thejournalofbusiness.org/index.php/site

Muhamad, R., Shahimi, S., Yahya, Y., \& Mahzan, N. (2009). Disclosure quality on governance issues in annual reports of Malaysian PLCs. International Business Research, 2(4), 61-72.

Naude, M. J., \& Chiweshe, N. (2017). A proposed operational risk management framework for small and medium enterprises. South African Journal of Economic and Management Sciences, 20(1), 1-10. https://doi.org/10.4102/sajems.v20i1.1621

Neifar, S., \& Jarboui, A. (2018). Corporate governance and operational risk voluntary disclosure: Evidence from Islamic banks. Research in International Business and Finance, 46(146), 43-54. https://doi. org/10.1016/j.ribaf.2017.09.006

Nguyen, Ho, \& Vo. (2019). An empirical test of capital structure theories for the Vietnamese listed firms. Journal of Risk and Financial Management, 12(3), 148. https://doi.org/10.3390/jrfm12030148

Nielsen, S., \& Huse, M. (2010). Women directors' contribution to board decision-making and strategic involvement: The role of equality perception. European Management Review, 7(7), 16-29.

Nobanee, H., \& Ellili, N. (2017). Does operational risk disclosure quality increase operating cash flows? BAR - Brazilian Administration Review, 14(4), 1-13. https://doi.org/10.1590/1807-7692bar2017170025

Ntim, C. G., Lindop, S., \& Thomas, D. A. (2013). Corporate governance and risk reporting in South Africa: A study of corporate risk disclosures in the pre- and post-2007/2008 global financial crisis periods. International Review of Financial Analysis, 30, 363-383. https://doi.org/10.1016/j. irfa.2013.07.001 
Nugraheni, P., \& Azlan Anuar, H. (2014). Implications of Shariah on the voluntary disclosure of Indonesian listed companies. Journal of Financial Reporting and Accounting, 12(1), 76-98. https://doi. org/10.1108/jfra-11-2011-0018

Othman, R., \& Thani, A. M. (2010). Islamic social reporting of listed companies in Malaysia. International Business \& Economics Research Journal, 9(4), 135-144. https://doi.org/10.2308/accr.2008.83.3.629

Ousama, A. A., \& Fatima, A. H. (2010). Voluntary disclosure by Shariah approved companies: An exploratory study. Journal of Financial Reporting and Accounting, 8(1), 35-49. https://doi. org/10.1108/19852511011055943

Probohudono, A. N., Tower, G., \& Rusmin, R. (2013). Risk disclosure during the global financial crisis. Social Responsibility Journal, 9(1), 124-137.

Ramli, N., Ismail, R. F., Ab Samad, N. H., \& Zainon, S. (2019). An empirical study on capital structure decisions in determining risk information disclosure in bursa Malaysia ACE market. International Journal of Innovation, Creativity and Change, 7(5).

Rosli, N. F., Mohammed, N. F., \& Sanusi, Z. M. (2017). The determinants of voluntary risk disclosures: The case of Shariah compliant companies in Malaysia. SHS Web of Conferences, 36, 00002. https://doi.org/10.1051/ shsconf/20173600002

Saggar, R., \& Singh, B. (2017). Corporate governance and risk reporting: Indian evidence. Managerial Auditing Journal, 32(4-5), 378-405. https://doi.org/10.1108/MAJ-03-2016-1341

Samaha, K., Khlif, H., \& Hussainey, K. (2015). The impact of board and audit committee characteristics on voluntary disclosure: A metaanalysis. Journal of International Accounting, Auditing and Taxation, 24, 13-28. https://doi.org/10.1016/j.intaccaudtax.2014.11.001

Siman, R., Ismail, R. F., Aziz@ Omar, Z., \& Mohd Zam, Z. (2019). Board of directors and environmental reporting: Evidence from plantation 
industry. The Journal of Social Sciences Research, (Special Issue 5), 916-925. https://doi.org/10.32861/jssr.spi5.916.925

Soong, Y. Q., \& Hooy, C. W. (2016). Does women directorship in malaysian government-linked companies matters? Journal of Contemporary Issues and Thought, 6, 83-92. Retrieved from https://ejournal.upsi.edu.my/ index.php/JCIT/article/view/1070

Sulong, Z., Gardner, J. C., Hussin, A. H., Mohd Sanusi, Z. \& McGowan Jr., C. B. (2013). Managerial ownership, leverage and audit quality impact on firm performance: Evidence from the Malaysian ACE market. Accounting \& Taxation, 5(1), 59-71.

Sun, W., \& Cui, K. (2014). Linking corporate social responsibility to firm default risk. European Management Journal, 32(2), 275-287. https:// doi.org/10.1016/j.emj.2013.04.003

Tengku Sulaiman, T. I. N., \& Ahmad, N. S. (2017). Factors that influence corporate governance failures In Malaysia. FGIC 1st Conference on Governance \& Integrity, (April), 3-4.

Wan Ismail, W. A., Kamarudin, K. A., \& Sarman, S. R. (2015). The quality of earnings in Shariah-compliant companies: Evidence from Malaysia. Journal of Islamic Accounting and Business Research, 6(1), 19-41. https://doi.org/10.1108/JIABR-03-2013-0005

Zahid, M., Rahman, H. U., Ali, W., Khan, M., Alharthi, M., Imran Qureshi, M., \& Jan, A. (2019). Boardroom gender diversity: Implications for corporate sustainability disclosures in Malaysia. Journal of Cleaner Production, 244(October), 118683. https://doi.org/10.1016/j. jclepro.2019.118683

Zattoni, A., \& Cuomo, F. (2010). How independent, competent and incentivized should non-executive directors be ? An empirical investigation of good governance codes. British Journal of Management, 21, 63-79. https://doi.org/10.1111/j.1467-8551.2009.00669.x 